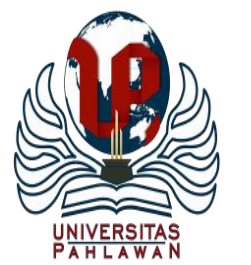

Edukatif : Jurnal Ilmu Pendidikan Volume 3 Nomor 3 Tahun 2021 Halm 943 - 950

EDUKATIF: JURNAL ILMU PENDIDIKAN

Research \& Learning in Education

https:/ledukatif.org/index.php/edukatif/index

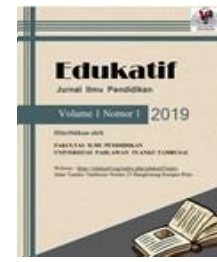

\title{
Perkembangan Pembelajaran Daring terhadap Minat Belajar Matematika Siswa SMP pada Masa Pandemi COVID-19
}

\author{
Zahra Alhumairah Basa ${ }^{1 凶}$, Hudaidah $^{2}$ \\ Universitas Sriwijaya, Indonesia ${ }^{1,2}$ \\ E-mail : $\underline{\text { bzahraalhumairah@ gmail.com }}{ }^{1}, \underline{\text { Hudaidah @ fkip.unsri.ac.id }}^{2}$
}

\begin{abstract}
Abstrak
Penyebaran COVID-19 yang sangat cepat di Indonesia menyebabkan semua kegiatan pembelajaran dialihkan menjadi secara daring. Sistem pendidikan pembelajaran daring pada masa pandemi COVID-19 dilakukan dari rumah yang bertujuan untuk mengurangi penyebaran virus COVID-19. Sistem pendidikan pembelajaran daring dari rumah sudah sesuai dengan kurikulum 2013, namun pembelajaran secara daring ini memiliki dampak positif maupun negatif yang mempengaruhi minat belajar siswa SMP terhadap pembelajaran matematika. Artikel ini bertujuan untuk memaparkan perkembangan pembelajaran daring terhadap minat belajar matematika siswa SMP pada masa pandemi COVID-19 serta mengetahui kesulitan siswa SMP terhadap pembelajaran matematika secara daring. Metode penelitian yang digunakan adalah penelitian kepustakaan. Penelitian kepustakaan bersumber dari artikel, berita, dan dokumen yang berhubungan dengan pembelajaran daring dan minat belajar matematika siswa pada masa pandemi COVID-19. Metode penelitian kepustakaan dilakukan dengan mencari dan mengumpulkan sumber yang relevan dengan topik yang dibahas. Data yang sudah dikumpulkan selanjutnya dianalisis menggunakan metode deskriptif. Pada metode deskriptif mengungkap fakta kejadian dan ditulis dalam pernyataan-pernyataan yang bersumber dari data yang diteliti. Hasil penelitian ini menjelaskan bagaimana proses dari permasalahan pembelajaran daring pada masa pandemi COVID-19.
\end{abstract}

Kata Kunci: Pembelajaran, Matematika, COVID-19.

\section{Abstract}

The rapid spread of COVID-19 in Indonesia causes learning activities are switched to online learning. The online learning system in COVID-19 pandemic is carried out from home to suppress the spread of COVID-19. The online learning is based on curriculum 2013, but it holds both positive and negative effects that affect junior high school students' interest in mathematics subject. This article aims to explain the development of online learning on junior high school students' interest in mathematics during the COVID-19 pandemic and to find out the difficulties that the students encounter in mathematics online learning. The method used in this research is library research. The literature is sourced from articles, news, and documents related to online learning and students' interest in studying mathematics during the COVID-19 pandemic. The library research is done by locating and gathering relevant sources on the topic being discussed. The data that has been collected were then analyzed using descriptive method. It reveals the facts based on the events and written in the statements derived from the data studied. The results of this study explain the process of learning problems on the online learning during the COVID-19 pandemic.

Keywords: Learning, Mathematics, COVID-19.

Copyright (c) 2021 Zahra Alhumairah Basa, Hudaidah

$\triangle$ Corresponding author

Email : bzahraalhumairah@gmail.com

DOI $:$ https://doi.org/10.31004/edukatif.v3i3.461

ISSN 2656-8063 (Media Cetak)

ISSN 2656-8071 (Media Online)

Edukatif : Jurnal Ilmu Pendidikan Vol 3 No 3 Tahun 2021 p-ISSN 2656-8063 e-ISSN 2656-8071 
944 Perkembangan Pembelajaran Daring terhadap Minat Belajar Matematika Siswa SMP pada Masa Pandemi COVID-19 - Zahra Alhumairah Basa, Hudaidah

DOI: https://doi.org/10.31004/edukatif.v3i3.461

\section{PENDAHULUAN}

Pendidikan adalah usaha sadar manusia yang sistematis dalam mewujudkan suasana dan proses pembelajaran secara aktif mengembangkan potensi diri peserta didik. Pendidikan dapat diperoleh peserta didik secara formal maupun non formal. Pendidikan secara formal didapat dengan mengikuti program yang telah direncanakan oleh kementerian negara. Menurut Kamus Besar Bahasa Indonesia (KBBI) menjelaskan bahwa pendidikan adalah cara atau proses pengubahan sikap serta tata laku seseorang atau kelompok orang dalam usaha mendewasakan manusia melalui upaya pengajaran ataupun pelatihan.

Setiap warga negara Indonesia memiliki hak untuk memperoleh pendidikan yang bermutu dan warga negara bertanggung jawab terhadap keberlangsungan penyelenggaraan pendidikan. Menurut Undang-Undang Nomor 20 Tahun 2003 menjelaskan bahwa pendidikan adalah usaha secara sadar serta terencana manusia yang bertujuan untuk mewujudkan suasana dan proses pembelajaran agar peserta didik aktif mengembangkan potensi dirinya untuk memiliki kekuatan keagamaan, spiritual, kepribadian, pengenalan diri, akhlak mulia, kecerdasan, serta keterampilan yang diperlukan peserta didik, masyarakat, maupun negara.

Pembelajaran merupakan proses dari interaksi pendidik dan peserta didik yang bertujuan membantu dan mempengaruhi proses belajar peserta didik dengan serangkaian kegiatan belajar. Menurut Undang-Undang Nomor 20 Tahun 2003 tentang Sistem Pendidikan Nasional Pasal 1 Ayat 20 menjelaskan bahwa pembelajaran adalah cara atau proses interaksi peserta didik dengan pendidik dan sumber belajar pada suatu lingkungan belajar. Pembelajaran yang kreatif dan inovatif seharusnya dilakukan oleh pendidik agar menghasilkan peserta didik yang kreatif dan inovatif dalam belajar. Kualitas pembelajaran dapat dilihat dari aktivitas dan kreativitas peserta didik pada saat mengikuti pembelajaran.

Novel Coronavirus atau COVID-19 adalah penyakit yang disebabkan oleh virus (SARS-CoV-2) atau serve acute respiratory syndrome coronavirus 2 yang menjadi penyebab wabah pneumonia. Pada bulan Desember tahun 2019 dunia gempar dengan kabar kemunculan coronavirus (2019-nCoV) di kota Wuhan, Tiongkok. Individu yang terjangkit virus ini mengalami gejala seperti pneumonia berat, gangguan pernapasan akut, edema paru, dan meninggal. Jumlah kasus yang terinfeksi COVID-19 terus bertambah cepat dan menyebar ke beberapa negara lain. Pada tanggal 11 Maret 2020 WHO menetapkan COVID-19 sebagai pandemi dikarenakan tingkat penyebaran dan jumlah kasus yang terus bertambah.

Penyebaran COVID-19 sangat berdampak pada dunia ekonomi, tetapi sekarang dampaknya juga dirasakan oleh sistem pendidikan di Indonesia. Kebijakan yang diputuskan oleh beberapa negara termasuk Indonesia yaitu dengan meliburkan semua aktivitas pendidikan yang membuat pemerintah dan lembaga terkait tersebut harus memberikan alternatif dari proses pembelajaran untuk peserta didik ataupun mahasiswa yang tidak dapat melaksanakan proses pendidikan pembelajaran di lembaga pendidikan (Dewi, 2020). Pada tanggal 17 Maret 2020 Menteri Pendidikan dan Kebudayaan mengeluarkan surat edaran memberlakukan pembelajaran secara daring dari rumah bagi siswa dan mahasiswa dalam hal mencegah penyebaran COVID19 di Indonesia (Kementerian Pendidikan dan Kebudayaan Republik Indonesia, 2020). Pembelajaran daring dapat dilakukan menggunakan e-learning ataupun menggunakan aplikasi pihak ketiga yang dapat mendukung proses pembelajaran secara daring seperti Zoom Meeting, Google Classroom, Google Meet, dan CloudX (Hutomo Atman Maulana, 2021).

Matematika merupakan salah satu mata pelajaran yang diajarkan oleh pendidik di sekolah dan dinilai memegang peranan cermat, rasional, kritis, efektif dan efisien. Dalam etimologi, matematika berasal dari bahasa Yunani Kuno yang memiliki arti sebagai ilmu pengetahuan, pengetahuan, dan belajar. Matematika adalah ilmu pengetahuan tentang pengukuran kuantitas, struktur, bilangan, geometri, dan perubahan. Matematika adalah salah satu dari cabang ilmu pengetahuan yang memiliki peranan penting bagi perkembangan ilmu pengetahuan serta teknologi, baik itu sebagai alat bantu bagi penerapan bidang ilmu lain ataupun bagi pengembangan dari ilmu matematika. Penguasaan materi matematika dari peserta didik menjadi 
945 Perkembangan Pembelajaran Daring terhadap Minat Belajar Matematika Siswa SMP pada Masa Pandemi COVID-19 - Zahra Alhumairah Basa, Hudaidah

DOI: https://doi.org/10.31004/edukatif.v3i3.461

suatu kewajiban di dalam penataan nalar dan pengambilan keputusan dalam era persaingan yang semakin kompetitif pada saat ini (Muhammad Daut Siagian, 2016).

Pembelajaran matematika perlu dipersiapkan dengan maksimal seperti menggunakan berbagai macam model pembelajaran karena pada pembelajaran matematika lebih menekan keterlibatan peserta didik dan mengarahkan untuk aktif dalam proses pembelajaran. Pembelajaran matematika yang kurang dalam melibatkan peserta didik untuk aktif akan menyebabkan peserta didik tidak dapat menggunakan secara optimal kemampuan matematikanya dalam menyelesaikan permasalahan matematika. Selain itu, setelah masuknya COVID-19 di Indonesia menyebabkan pembelajaran matematika dilaksanakan secara daring dan membuat proses pengajaran sedikit terhambat karena terkendala dalam menjelaskan materi yang tidak bisa dijelaskan secara langsung.

Berdasarkan penjabaran diatas, artikel ini dibuat untuk memaparkan perkembangan pembelajaran daring terhadap minat belajar matematika siswa SMP pada masa pandemi COVID-19, mengetahui kesulitan siswa SMP terhadap pembelajaran matematika secara daring, dan memberikan solusi yang tepat untuk permasalahan yang terjadi pada pembelajaran matematika secara daring agar pendidikan di Indonesia bisa terus berkembang menjadi lebih baik.

\section{METODE}

Metode yang digunakan penulis untuk mengumpulkan informasi terkait dengan topik yang dibahas adalah metode penelitian kepustakaan. Pada metode ini penulis melakukan identifikasi jurnal-jurnal secara sistematis dan setiap prosesnya mengikuti langkah-langkah yang sudah ditetapkan. Data pendukung diperoleh dari berbagai sumber seperti dokumen, artikel ilmiah yang berasal dari jurnal ilmiah, berita yang berkaitan dengan perkembangan pembelajaran daring terhadap minat belajar matematika siswa SMP pada masa pandemi COVID-19. Data yang sudah dikumpulkan selanjutnya dianalisis menggunakan metode deskriptif. Pada metode deskriptif mengungkap fakta kejadian dan ditulis dalam pernyataan-pernyataan yang bersumber dari data yang diteliti.

\section{HASIL DAN PEMBAHASAN}

COVID-19 atau Novel Coronavirus merupakan virus yang disebabkan oleh virus serve acute respiratory syndrome coronavirus 2 (SARS-CoV-2) dan menyebabkan penyakit mulai dari gejala yang ringan sampai gejala yang berat seperti pneumonia berat, infeksi saluran pernapasan, gangguan pernapasan ringan hingga akut, edema paru, dan bisa menyebabkan manusia meninggal. Penyebaran COVID-19 ini sangat cepat sehingga mengakibatkan dampak yang serius bagi semua negara khususnya Indonesia. Kegiatan pembelajaran sekolah terkendala dan dialihkan menjadi pembelajaran secara daring di rumah peserta didik masing-masing sesuai dengan surat edaran Menteri Pendidikan dan Kebudayaan yang memberlakukan pembelajaran secara daring dari rumah bagi siswa dan mahasiswa dalam hal mencegah penyebaran COVID-19 di Indonesia.

Pembelajaran daring tidak melakukan pembelajaran tatap muka secara langsung, namun menggunakan fasilitas internet yang bisa membantu proses pengajaran jarak jauh (Handarini \& Wulandari, 2020). Pembelajaran daring bukan sekadar materi pelajaran yang pindah melalui media internet dan bukan juga sekadar tugas yang diberikan melalui aplikasi sosial media tetapi pembelajaran dari ini harus direncanakan, dilakukan atau dilaksanakan, serta dievaluasi sama halnya dengan pembelajaran yang terjadi di kelas secara luring (Yunitasari \& Hanifah, 2020). Pada jenjang Sekolah Menengah Pertama (SMP) pembelajaran daring dilaksanakan dengan bantuan orang tua sebagai pembimbing peserta didik dalam proses pembelajaran di rumah. Pelaksanaan pembelajaran secara daring ini didukung juga oleh perangkat pembelajaran seperti smartphone, laptop, kuota internet, dan koneksi internet yang stabil.

Pembelajaran secara daring di rumah peserta didik masing-masing menggunakan sistem pembelajaran yang memanfaatkan teknologi sebagai media pembelajaran. Pertemuan secara virtual memanfaatkan teknologi 
946 Perkembangan Pembelajaran Daring terhadap Minat Belajar Matematika Siswa SMP pada Masa Pandemi COVID-19 - Zahra Alhumairah Basa, Hudaidah

DOI: https://doi.org/10.31004/edukatif.v3i3.461

seperti Zoom Meeting dan Google Meet. Pemberian tugas oleh pengajar dan pengiriman hasil tugas oleh peserta didik memanfaatkan teknologi seperti Google Classroom, E-learning, Kahoot, Quizizz dan Google Form. Platform yang menyediakan jasa pembelajaran tambahan seperti Ruangguru, Zenius, Quipper, Edmodo, Rumah Belajar, Kelas Pintar, Pahamify, Youtube dan sebagainya. Teknologi lain yang bisa membantu pengajar khususnya pengajar matematika dalam menjelaskan materi yang perlu visualisasi bisa memanfaatkan fasilitas internet seperti GeoGebra.

Salah satu tugas dari pendidik yaitu dapat menyediakan suasana belajar yang menyenangkan bagi peserta didik. Pendidik harus bisa mencari cara dalam membuat pembelajaran menjadi lebih menyenangkan dan mencegah ancaman selama proses pembelajaran (Nugraha et al., 2020). Salah satu cara yang bisa membuat pembelajaran menjadi lebih menyenangkan dan dapat menambah minat belajar peserta didik serta senang dalam mempelajari materi pelajaran khususnya matematika yaitu dengan menggunakan media pembelajaran yang menarik contohnya berupa video pembelajaran dan juga bisa memanfaatkan fasilitas di internet. Pendidik tidak hanya menggunakan soft file berupa teks namun menambah metode pembelajaran menggunakan video penjelasan materi. Pendidik juga memiliki tujuan agar peserta didik berhasil mencapai proses pembelajaran dengan baik, karena tujuan ini sebagai tolok ukur keberhasilan dalam proses pembelajaran. Agar tujuan tersebut dapat dicapai dan meningkatkan hasil belajar peserta didik, pendidik harus bisa memilih metode pembelajaran yang tepat untuk diterapkan pada kondisi pandemi sekarang ini.

Matematika adalah ilmu yang mempelajari tentang bilangan, struktur, dan model yang terorganisasi. Pada pelajaran matematika membahas seperti definisi, teorema, postulat, korelasi, dan fakta yang bersifat deduktif. Matematika merupakan salah satu pelajaran yang sampai saat ini masih dianggap sulit oleh para siswa. Padahal di sisi lain, matematika adalah salah satu subjek yang paling penting dalam kehidupan manusia. Matematika berperan dalam hampir semua aspek bahkan pada masa teknologi dan digital sekarang (Siregar, 2017). Pembelajaran matematika perlu dipersiapkan pendidik dengan lebih maksimal bisa menggunakan berbagai jenis model pembelajaran karena dalam pembelajaran matematika lebih menekankan keterlibatan peserta didik untuk aktif pada saat proses pembelajaran.

Beberapa faktor yang dapat mempengaruhi keberhasilan peserta didik dalam belajar matematika yaitu dari faktor internal dan faktor eksternal. Faktor internal yaitu seperti kemampuan awal atau kemampuan dasar, tingkat kecerdasan dari individu peserta didik, minat belajar atau motivasi belajar, kebiasaan belajar peserta didik, kecemasan peserta didik dalam belajar, dan sebagainya. Faktor eksternal yaitu seperti lingkungan keluarga dari peserta didik, keadaan sosial dan ekonomi keluarga, lingkungan masyarakat, lingkungan sekolah, dan sebagainya (Lestari, 2017). Kemampuan awal dari peserta didik merupakan salah satu faktor penentu dalam keberhasilan pembelajaran matematika tetapi setiap peserta didik memiliki kemampuan belajar yang berbeda. Kemampuan awal dari peserta didik merupakan kemampuan yang telah dimiliki oleh peserta didik sebelum mengikuti pembelajaran matematika yang akan diberikan oleh pendidik. Kemampuan awal ini menggambarkan dari kesiapan peserta didik dalam menerima materi matematika yang akan disampaikan oleh pendidik.

Efektivitas pembelajaran di sekolah merupakan salah satu indikator penting yang menentukan keberhasilan proses pembelajaran. Interaksi atau hubungan antara pendidik dan peserta didik dengan sumber belajar meliputi berbagai aspek yang hakikatnya masih menjadi bagian dalam perangkat pelaksanaan pendidikan. Oleh karena itu, pada pelaksanaannya muncul berbagai inovasi sebagai bentuk respon dalam menjawab persoalan yang timbul selama proses pembelajaran (Hasanah et al., 2020).

Materi pelajaran matematika siswa SMP yang memerlukan bantuan dalam visualisasi contohnya seperti materi geometri. Geometri adalah salah satu bidang dalam materi matematika yang mempelajari titik, garis, bidang, dan ruang beserta sifat, ukuran, dan keterkaitan satu sama lain. Jika dibandingkan geometri dengan bidang-bidang lain dalam materi matematika, geometri adalah salah satu bidang dalam materi matematika yang dianggap paling sukar untuk dipahami. Geometri diajarkan dengan tujuan agar peserta didik bisa 
947 Perkembangan Pembelajaran Daring terhadap Minat Belajar Matematika Siswa SMP pada Masa Pandemi COVID-19 - Zahra Alhumairah Basa, Hudaidah

DOI: https://doi.org/10.31004/edukatif.v3i3.461

memahami sifat dan hubungan antar unsur geometri serta mendorong peserta didik untuk berpikir secara kritis dalam memecahkan permasalahan dalam kehidupan sehari-hari (Fauzi \& Arisetyawan, 2020).

Geometri berkaitan dengan pembentukan dari konsep abstrak, akibatnya pembelajaran ini tidak bisa hanya dilakukan dengan metode ceramah saja tetapi pembentukan konsep melalui rangkaian kegiatan siswa secara langsung. Pada masa pandemi ini pendidik bisa menggunakan media pembelajaran seperti GeoGebra dalam memberikan visualisasi materi geometri. Program GeoGebra dapat dikatakan dirancang untuk tujuan pendidikan khususnya pembelajaran matematika dalam materi aljabar dan geometri. Melalui penggunaan media pembelajaran seperti media aplikasi, siswa SMP akan sangat terbantu dalam memahami konsep matematika. Setiap bidang dalam materi matematika memiliki tool yang berbeda dikarenakan objek kajiannya berbeda juga. GeoGebra dapat berfungsi sebagai media pembelajaran yang bisa memberikan visualisasi kepada siswa SMP dalam berinteraksi dengan objek-objek matematika. Hal tersebut dapat mendorong motivasi ataupun minat belajar siswa SMP karena mempermudah pemahaman terhadap objek-objek matematika yang bersifat abstrak (Nur'aini et al., 2017).

Pembelajaran secara daring dapat memberikan metode pembelajaran yang efektif karena menggabungkan kolaborasi kegiatan belajar mandiri dan pemanfaatan fasilitas internet oleh peserta didik. Namun kelangsungan pendidikan pembelajaran secara daring pada masa pandemi tergantung pada berbagai faktor, seperti tingkat persiapan dari sekolah, kesiapan orang tua dari segi ekonomi, dan kesiapan pendidik untuk mengajar peserta didik dengan kondisi yang tidak melakukan tatap muka secara langsung. Pertimbangan harus dilakukan pada kebutuhan semua peserta didik untuk bisa terus melanjutkan pembelajaran secara daring tanpa adanya kendala.

Potensi peserta didik yang baik dan sarana belajar yang sudah lengkap jika tidak disertakan motivasi dan minat belajar dari peserta didik, maka proses pembelajaran tidak akan berjalan dengan maksimal. Pada dasarnya setiap anak memiliki potensi yang tidak terbatas tetapi terdapat beberapa faktor yang dapat mempengaruhi potensi tersebut. Keterlibatan orang tua sangat penting untuk anak berprestasi di sekolah (E. Utami, 2020). Sehingga bisa dikatakan bahwa pencapaian tugas belajar peserta didik ditentukan oleh proses yang ada di dalamnya, jika proses berjalan maksimal baik dari pendidik dan peserta didik serta lingkungan maupun sarana pembelajaran maka hasilnya akan maksimal juga. Semakin tinggi kemampuan awal dari peserta didik sebelum mengikuti pembelajaran matematika selanjutnya maka akan semakin tinggi juga hasil belajar yang akan diraih peserta didik. Ditambah juga jika minat belajar peserta didik tersebut tinggi dan dapat memaksimalkan potensi sumber daya yang ia miliki.

Kenyataannya pendidik dan peserta didik banyak sekali mengalami berbagai kendala dalam pembelajaran secara daring. Adapun kendala atau kesulitan siswa SMP yang sering terjadi pada pembelajaran matematika secara daring yaitu 1) siswa belum memiliki inisiatif belajar sendiri, akibatnya siswa hanya menunggu instruksi pendidik dalam pemberian tugas belajar, 2) siswa belum terbiasa dalam melaksanakan kegiatan belajar secara daring di rumah dan hanya mempelajari materi matematika sesuai yang diberikan pendidik saja bukan materi yang diperlukan untuk dipelajari secara mandiri, 3) tujuan ataupun target belajar siswa secara daring terhadap pelajaran matematika hanya sebatas pada perolehan nilai yang memuaskan bukan ingin meningkatkan kemampuan diri dalam pemahaman materi, 4) sebagian siswa hanya belajar seperlunya dan belum bisa memonitor dan mengontrol belajar daring di rumah, 5) siswa jarang melakukan evaluasi proses dan hasil belajar serta siswa juga mengalami kendala dalam menyerahkan tugas di e-learning (Y. P. Utami et al., 2020).

Berdasarkan penelitian deskriptif dari (Mustakim, 2020) menggambarkan hanya beberapa peserta didik yang menyukai pembelajaran secara daring yakni sebesar $26,7 \%$, yang menyukai pembelajaran blended atau perpaduan luring dan daring sebesar $26,7 \%$, dan yang menyukai pembelajaran secara luring sebesar 46,6\%. Pembelajaran matematika secara daring juga memiliki kelebihan seperti peserta didik dapat mendapatkan sumber pembelajaran matematika lain melalui internet, bisa mengakses pembelajaran matematika yang tidak 
948 Perkembangan Pembelajaran Daring terhadap Minat Belajar Matematika Siswa SMP pada Masa Pandemi COVID-19 - Zahra Alhumairah Basa, Hudaidah

DOI: https://doi.org/10.31004/edukatif.v3i3.461

terbatas dalam jarak maupun waktu, pembelajaran lebih fleksibel karena dapat dilakukan dimana saja, menghemat pengeluaran biaya transportasi, materi dapat disimpan lalu diputar ulang jika peserta didik kurang paham, dan peserta didik bisa mengikuti perkembangan dan kemajuan teknologi (Ainur Risalah et al., 2020). Tetapi, pembelajaran secara daring membutuhkan gawai yang tersambung dalam koneksi internet yang stabil. Ada saatnya kondisi kebutuhan seperti perangkat yang harus ada namun belum dapat terpenuhi, baik dari pendidik maupun dari peserta didik. Hal tersebut berdampak pada proses pembelajaran khususnya pembelajaran matematika. Kendala lain pada saat pembelajaran secara daring pada pelajaran matematika yaitu tidak tersedianya gawai, sinyal atau koneksi internet yang tidak stabil di daerah tertentu, dan peserta didik sulit memahami materi matematika (Proborini, 2021). Selain itu, peserta didik banyak yang mengalami kejenuhan dan kebosanan dalam belajar secara daring sehingga terkadang peserta didik menjawab soal secara asalasalan. Kendala peserta didik yang merasakan kebosanan ini mengakibatkan pendidik harus memikirkan strategi berupa metode pembelajaran lain tentang bagaimana cara agar peserta didik keluar dari zona kebosanan mereka (Anugrahana, 2020).

Oleh karena itu, pelaksanaan pembelajaran matematika secara daring yang telah dilaksanakan pada masa pandemi ini dirasa kurang efektif diterapkan pada Siswa Menengah Pertama (SMP) karena fasilitasfasilitas pendukung pembelajaran daring belum terpenuhi, tetapi karena dalam masa pandemi dan demi mengurangi penyebaran virus COVID-19 pembelajaran secara daring ini merupakan alternatif yang tepat. Kedepannya diperlukan evaluasi secara menyeluruh terhadap pembelajaran daring. Kapasitas pendidik dan kemampuan orang tua menjadi salah satu pertimbangan yang penting dalam membangun sistem pembelajaran daring yang efektif (Khayat, 2021). Diperlukan perbaikan-perbaikan yang harus dilakukan oleh pemerintah untuk memfasilitasi sarana prasarana pembelajaran secara daring khususnya penyediaan dan pembagian kuota internet secara merata, peningkatan kemampuan pendidik serta peserta didik menggunakan teknologi dalam mendukung strategi belajar yang menyenangkan, dan dibutuhkan peranan orang tua dalam memfasilitasi kebutuhan belajar peserta didik (Medita Ayu Wuladari, Hana Sakura Putu Arga, Jajang Bayu Kelana, Deden Herdiana Altaftazani, 2020).

\section{KESIMPULAN}

Berdasarkan penjabaran di atas dapat disimpulkan bahwa penyebaran virus COVID-19 yang masuk ke Indonesia memberikan dampak yang besar pada bidang pendidikan dan mengakibatkan sistem pembelajaran dilaksanakan secara daring dari rumah peserta didik masing-masing. Pembelajaran matematika secara daring memiliki kelebihan dan kekurangan. Kelebihan dari pembelajaran matematika secara daring yaitu seperti peserta didik dapat mencari sumber pembelajaran matematika tambahan melalui fasilitas internet, bisa mengakses pembelajaran matematika yang tidak terbatas dalam jarak maupun waktu, pembelajaran lebih fleksibel karena dapat dilakukan dimana saja. Kekurangan dari pembelajaran matematika secara daring yaitu seperti tidak semua peserta didik memiliki gawai, sinyal atau koneksi internet yang tidak stabil di daerah tertentu, dan peserta didik sulit memahami materi matematika yang memerlukan visualisasi secara langsung. Dalam hal ini, peran dari pendidik diperlukan untuk terus berinovasi memberikan metode pembelajaran yang tepat dan efektif agar tujuan pembelajaran dapat dicapai. Pendidik dapat memanfaatkan fasilitas internet untuk menunjang media pembelajaran yang akan digunakan. Dibutuhkan juga kerja sama antara pendidik dan orang tua, untuk orang tua diharapkan bisa mendampingi anak selama pembelajaran secara daring dari rumah masing-masing sehingga terdapat hubungan timbal balik antara pendidik, peserta didik, dan orang tua agar pembelajaran khususnya matematika secara daring menjadi lebih efektif.

\section{DAFTAR PUSTAKA}

Ainur Risalah, W Ibad, L Maghfiroh, M I Azza, S A Cahyani, \& Z A Ulfayati. (2020). Dampak Pandemi Covid-19 Terhadap Kegiatan Belajar Mengajar Di MI/SD (Studi KBM Berbasis Daring Bagi Guru dan 
949 Perkembangan Pembelajaran Daring terhadap Minat Belajar Matematika Siswa SMP pada Masa Pandemi COVID-19 - Zahra Alhumairah Basa, Hudaidah

DOI: https://doi.org/10.31004/edukatif.v3i3.461

Siswa). JIEES: Journal of Islamic Education at Elementary School, 1(1), 10-16. https://doi.org/10.47400/jiees.v1i1.5

Anugrahana, A. (2020). Hambatan, Solusi dan Harapan: Pembelajaran Daring Selama Masa Pandemi Covid19 Oleh Guru Sekolah Dasar. Scholaria: Jurnal Pendidikan dan Kebudayaan, 10(3), 282-289. https://doi.org/10.24246/j.js.2020.v10.i3.p282-289

Dewi, W. A. F. (2020). Dampak COVID-19 terhadap Implementasi Pembelajaran Daring di Sekolah Dasar. Edukatif: Jurnal Ilmu Pendidikan, 2(1), 55-61. https://doi.org/10.31004/edukatif.v2i1.89

Fauzi, I., \& Arisetyawan, A. (2020). Analisis Kesulitan Belajar Siswa pada Materi Geometri Di Sekolah Dasar. Kreano, Jurnal Matematika Kreatif-Inovatif, 11(1), 27-35.

Handarini, O. I., \& Wulandari, S. S. (2020). Pembelajaran Daring sebagai Upaya Study From Home (SFH) Selama Pandemi Covid 19. Jurnal Pendidikan Administrasi Perkantoran (JPAP), 8 https://doi.org/10.1093/fampra/cmy005

Hasanah, R., Khaulah, S., \& Husnidar. (2020). Efektivitas Pembelajaran Daring Pada Mata Pelajaran Matematika Selama Pandemi Covid-19 Di Smp Negeri 6 Samalanga. ASIMETRIS: Jurnal Pendidikan Matematika dan Sains, 1(2), 82-86.

Hutomo Atman Maulana. (2021). EDUKATIF : JURNAL ILMU PENDIDIKAN Persepsi Mahasiswa terhadap Pembelajaran Daring di Pendidikan Tinggi Vokasi : Studi Perbandingan antara Penggunaan Google Classroom dan Zoom Meeting Hutomo Atman Maulana. 3(1), 188-195.

Kementerian Pendidikan dan Kebudayaan Republik Indonesia. (2020). Surat Edaran Menteri Pendidikan dan Kebudayaan Republik Indonesia Nomor 35952/MPK.A/HK/2020. Mendikbud RI, 1-2. https://www.kemdikbud.go.id

Khayat, Z. (2021). CENDEKIA : Jurnal Ilmu Pengetahuan No.1 Vol.1 Januari Tahun 2021 132. 1(1), 132139.

Lestari, W. (2017). Pengaruh Kemampuan Awal Matematika dan Motivasi Belajar terhadap Hasil Belajar Matematika. Jurnal Analisa, 3(1), 76. https://doi.org/10.15575/ja.v3i1.1499

Medita Ayu Wuladari, Hana Sakura Putu Arga, Jajang Bayu Kelana, Deden Herdiana Altaftazani, S. R. (2020). Analisis Pembelajaran "Daring" Pada Guru Sekolah Dasar Di Era Covid-19. Jurnal Ilmiah P2M STKIP Siliwangi P2M STKIP Siliwangi, 7(2), 164-168.

Muhammad Daut Siagian. (2016). Kemampuan Koneksi Matematika Dalam Pembelajaran Matematika. MES (Journal of Mathematics Education and Science), 2, 58-67.

Mustakim, M. (2020). Efektivitas Pembelajaran Daring Menggunakan Media Online Selama Pandemi Covid19 Pada Mata Pelajaran Matematika. Al asma: Journal of Islamic Education, 2(1), 1. https://doi.org/10.24252/asma.v2i1.13646

Nugraha, S. A., Sudiatmi, T., \& Suswandari, M. (2020). Studi Pengaruh Daring Learning Terhadap Hasil Belajar Matematika Kelas IV. Jurnal Inovasi Penelitian, 1(3), 265-276.

Nur'aini, I. L., Harahap, E., Badruzzaman, F. H., \& Darmawan, D. (2017). Pembelajaran Matematika Geometri Secara Realistis Dengan GeoGebra. Matematika, 16(2), 1-6. https://doi.org/10.29313/jmtm.v16i2.3900

Proborini, E. (2021). Evaluasi Pembelajaran Matematika Secara Daring Pada Siswa Kelas VI SD Karangturi. Intelligentes Jurnal Pendidikan Fisika dan Sains, 2.

Siregar, N. R. (2017). Persepsi Siswa Pada Pelajaran Matematika: Studi Pendahuluan Pada Siswa yang Menyenangi Game. Prosiding Temu Ilmiah X Ikatan Psikologi Perkembangan Indonesia, 224-232.

Utami, E. (2020). Kendala dan Peran Orangtua dalam Pembelajaran Daring Pada Masa Pandemi Covid-19. Prosiding Seminar Nasional Pascasarjana.

Utami, Y. P., Alan, D., \& Cahyono, D. (2020). Study At Home: Analisis Kesulitan Belajar. Jurnal Ilmiah 
950 Perkembangan Pembelajaran Daring terhadap Minat Belajar Matematika Siswa SMP pada Masa Pandemi COVID-19 - Zahra Alhumairah Basa, Hudaidah

DOI: https://doi.org/10.31004/edukatif.v3i3.461

Matematika Realistik (JI-MR), 1(1), 20-26.

Yunitasari, R., \& Hanifah, U. (2020). Pengaruh Pembelajaran Daring terhadap Minat Belajar Siswa pada Masa COVID 19. Edukatif: Jurnal Ilmu Pendidikan, 2(3), 232-243. https://doi.org/10.31004/edukatif.v2i3.142 